\title{
Izabela Franckiewicz-Olczak*
}

\section{INTERPRETACJA SYTUACJI EKONOMICZNEJ ARTYSTÓW WSPÓŁCZESNYCH W POLSCE W ŚWIETLE KONCEPCJI ANOMII I DEWIACJI SPOŁECZNEJ}

\begin{abstract}
Abstrakt. Przenikanie się świata artystycznego z innymi światami go otaczającymi, szczególnie ze światem wolnorynkowej gospodarki, może powodować anomię i sprzyjać zachowaniom dewiacyjnym. Tekst, w oparciu o typologię mitów związanych z artystami, omawia obszary społecznego ich funkcjonowania, w których zaszły najdalej posunięte zmiany. Odwołując się do teorii dewiacji w interpretatywnym ujęciu Howarda S. Beckera, próbuje wykazać zmienność w czasie i względność dewiacyjności świata artystycznego, a sięgając po Mertonowskie typy idealnego przystosowania, obrazuje sposoby funkcjonowania artystów w bieżącej rzeczywistości społeczno-gospodarczej.

Słowa kluczowe: anomia, dewiacje, artyści, bezinteresowność artystyczna, wolność artystyczna, indywidualność, kariera artystyczna.

Co oznacza współcześnie bycie twórcą? Jak w bieżącej sytuacji społeczno-gospodarczej radzą sobie artyści? Jakie są najczęstsze scenariusze kariery artystów wizualnych? Last but not least jaka jest sytuacja ekonomiczna współczesnych artystów? To podstawowe pytania, na które spróbuje odpowiedzieć autorka w poniższym tekście. Analiza poprowadzona będzie w oparciu o badania kondycji sztuk wizualnych, prowadzone w 2015 roku w ramach programu MKiDN „Obserwatorium kultury”, którymi miałam okazję kierować1. Bezpośrednio będę się odwoływać do 85 wywiadów swobodnych z dyrektorami placówek wystawienniczych ${ }^{2}$ oraz 13 z artystami i 3 z artystkami. Poza nimi, w ramach badań terenowych, przeprowadzono 561 wywiadów kwestionariuszowych z odbiorcami sztuki współczesnej, 222 obserwacje odbioru artefaktów artystycznych. Badanie kwestionariuszowe i obserwacje realizowano w 32 muzeach (wszystkich posiadających w swych zbiorach sztukę współczesną), centrach sztuki współczesnej i wytypowanych placówkach galeryjnych na terenie całego kraju, zarówno

* Zakład Badań Komunikacji Społecznej, Instytut Socjologii Uniwersytetu Łódzkiego, e-mail: iza. franckiewicz@uni.lodz.p1/.

${ }^{1}$ Raport z badań jest dostępny na stronie: http://nck.pl/badania/raporty/kondycja-sztuk-wizualnych-percepcja-i-spoleczny-obieg-sztuki-wspolczesnej-w-polsce [dostęp 30.05.2018].

${ }^{2}$ Spośród 69 osób na stanowiskach dyrektorskich 41 stanowiły kobiety, a 29 mężczyźni.
\end{abstract}


finansowanych ze środków publicznych, jak i komercyjnych. Badanie terenowe poprzedzone było analizą materiałów zastanych.

Sytuacja społeczna współczesnego artysty zbudowana jest w oparciu o szereg sprzeczności wynikających z przeformatowań nie tylko świata artystycznego, ale życia społecznego i kultury współczesnej. W płynnej rzeczywistości zanikają do tej pory obowiązujące podziały pomiędzy światem sztuki ${ }^{3}$ a rzeczywistością pozaartystyczną. Rozwój sektorów kreatywnych, w których zatrudnionych jest coraz więcej osób, pozwala na wykonywanie prac twórczych osobom niezaliczanym do grona artystów, zaś nienormowany czas pracy, przenoszenie części obowiązków zawodowych do domów, stwarza warunki do upowszechnienia stylu życia do tej pory zarezerwowanego dla artystów. Kultura współczesna demokratyzuje kreatywność, która przestaje być przyrodzoną cechą wybranych, stając się dostępną każdemu kompetencją (Franczak 2015). Z kolei rozwój kapitalizmu i urynkowienie sztuki wymuszają na twórcach rozwój kompetencji przedsiębiorczych. Świat, w którym pieniądz staje się jedną z najważniejszych wartości, a sztuka kolejnym dobrem konsumpcyjnym, zmienia sytuację artystów. Załamanie dotychczasowych porządków, przenikanie się świata artystycznego z innymi światami go otaczającymi, szczególnie ze światem wolnorynkowej gospodarki, może powodować anomię. Ta zaś sprzyja zachowaniom dewiacyjnym. W dalszej części tekstu wskażę, w jakich obszarach społecznego funkcjonowania artystów w Polsce zaszły najdalej posunięte zmiany. Posłuży mi do tego typologia mitów świata artystycznego. Odwołując się do teorii dewiacji i etykietowania w interpretatywnym ujęciu Howarda S. Beckera, spróbuję wykazać zmienność w czasie i względność dewiacyjności świata artystycznego, by w końcu sięgając po Mertonowskie typy idealnego przystosowania, zobrazować sposoby funkcjonowania artystów w bieżącej rzeczywistości społeczno-gospodarczej.

Blisko dziesięć lat temu w tekście Rola artysty w społeczeństwie Ewelina Wejbert-Wąsiewicz (2009) przywoływała za Marianem Golką, Marią Gołaszewską i Andrzejem Osęką dwadzieścia mitów zbudowanych wokół artyzmu, które sprawują, zdaniem przytoczonej autorki, rolę uzasadnień twórczych ${ }^{4}$. Nie będę odnosić się do wszystkich zawartych w przywoływanym tekście mitów, a jedynie do tych, które w największym stopniu zostały podważone przez wskazane przeze mnie wyżej procesy. Konfrontowanie mitów dotyczących artystów z ich bieżącą sytuacją, wynikającą z zarysowanych zmian, pozwala spojrzeć na świat sztuki z perspektywy koncepcji anomicznych. Anomia, w klasycznym ujęciu

${ }^{3}$ Pojęć „świat artystyczny” i ,świat sztuki” używam wymiennie. Rozumiem je jako pewną sieć relacji pomiędzy podmiotami zajmującymi się sztuką, w tym przede wszystkim artystami. Jest to ujęcie obecne u Howarda S. Beckera (1982) i S. Thornton (2008)

${ }^{4}$ Wśród nich znalazły się: wyjątkowość, indywidualność, powołanie, wolność, cierpienie, szaleństwo, bunt, bluźnierstwo, spontaniczność, samotność, odrzucenie, zaangażowanie, egocentryzm, zabawa, oczyszczenie, bezinteresowność, mit artysty-kapłana, zbiorowego, antyartysty, sztuczności, odkrywcy. 
Émile’a Durkheima, wynika z nagłych zmian społecznych, załamania się porządku społecznego. Sytuacje anomiczne stwarzają grunt do zachowań o charakterze dewiacyjnym. Refleksje Howarda Beckera na temat dewiacji wynikają z obserwacji środowiska muzyków, zatem wprost odwołują się do świata artystycznego. Dla przytoczonego autora dewiacja jest wytworem grup społecznych, które tworzą reguły. Odstępstwo od nich jest dewiacją (Becker 2009: 13). Punkt ciężkości w jego analizach położony jest na to, jak rodzi się dewiacja, czyli jak to się dzieje, że określony czyn postrzegany jest jako dewiacyjny lub nie, a osoba go popełniająca otrzymuje etykietę dewianta. Interpretatywna perspektywa Beckera zwraca uwagę na istotne dla analizowanej problematyki kwestie: zmienność w czasie postrzegania określonych zachowań jako dewiacyjnych lub nie, sekwencyjność jednostkowych zachowań dewiacyjnych (kariera dewiacyjna), a także na fakt, że to, co w jednej grupie uważane jest za dewiację, w innej może uchodzić za zachowanie zupełnie normalne.

Przyjrzyjmy się zatem mitom bezinteresowności, wolności i indywidualności z perspektywy kultury współczesnej. Bezinteresowność w materialistycznym społeczeństwie postrzegana jest jako cnota uzupełniająca katalog zachowań ludzkich. Dla bezinteresowności znaleziono przestrzeń związaną z charytatywnością, nie jest ona jednak wymagana w życiu zawodowym. Bezinteresowność może być wręcz niebezpieczna (dewiacyjna). Zachowania bezinteresowne mogą bowiem wynikać z oczekiwania korzyści odroczonych. Bezinteresowność wreszcie może kojarzyć się z naiwnością, niezaradnością, a nawet szaleństwem. Bezinteresowność w zmitologizowanym świecie sztuki jest wartością, która ma pozwolić na wolność artystyczną, uwalniać artystę od trosk niezwiązanych z procesem twórczym. Artysta zanurzony jest $\mathrm{w}$ obu światach normatywnych. W spragmatyzowanym świecie, bezinteresowność artystyczna może być postrzegana jako przejaw naiwności. Ciekawa, w tym kontekście, choć nie bezpośrednio związana z bezinteresownością, jest wypowiedź jednego z twórców na temat statusu społecznego artysty:

Status artysty? To można na różnych płaszczyznach rozpatrywać. Na przykład na poziomie języka. Sam się przyłapałem na tym, że jechałem sobie samochodem i facet odwinął przede mną dosyć dziwny numer i ja sobie powiedziałem: „O, to artysta jest!”. Myślę sobie OK - przeniknęło, działa. Czyli artysta to głupek.

Historia sztuki karmi nas biografiami artystów niedbających o byt materialny, gotowych poświęcić wszystko dla sztuki, wyprzedzających swe czasy i dlatego docenianych dopiero po śmierci. Za przykład posłużyć mogą życiorysy Jana Vermeera - który umierając w 1675 roku, pozostawił rodzinę w licznych długach, Vincenta van Gogha - opisywanego jako malarza z ciągłymi problemami finansowymi, czy Paula Gauguina - który po porzuceniu na rzecz malarstwa pracy urzędniczej popadł w niekorzystną sytuację finansową. Jednocześnie współczesne media dostarczają rankingów najbogatszych artystów, czyniąc ich majętność 
elementem stratyfikacji nie tylko społecznej, ale i artystycznej. Status finansowy, również $\mathrm{w}$ świecie sztuki, staje się wyznacznikiem sukcesu. Pierwsze miejsce z majątkiem miliarda dolarów zajmuje Damien Hirst, drugą pozycję zajmuje Jeff Kunst z 500 milionami dolarów, a na dalszych pozycjach również plasują się artyści z milionowymi kontami, tacy jak: Jasper Johns, David Choe, Takashi Murakami, Anish Kapoor, Gerhard Richter i inni. Popkultura wykreowała nowy - konkurencyjny w stosunku do artysty bezinteresownego - model twórcy, którego talent, nawet jeśli nie jest liczony sumą dolarów na koncie, z pewnością nie jest poprzez nią deprecjonowany. Artyście dzisiaj wolno być bogatym. Jego zamożność sprawia, że zaczyna zdobywać szacunek nawet w kręgach społecznych w niewielkim stopniu zainteresowanych sztuką.

Choć bezinteresowność artystów w dobie późnego kapitalizmu przestała być determinantą artyzmu, artyści-milionerzy wciąż należą do rzadkości, a zdecydowana większość, szczególnie w polskich realiach, ma problem z uzyskaniem stabilności finansowej. Posiadająca ogólnoświatowy charakter dyskusja na temat ekonomicznej kondycji artystów sięga co najmniej lat 80., a na sile zyskuje dzięki refleksji związanej z klasą kreatywną ${ }^{5}$, problemem prekariatu ${ }^{6}$, czy szerzej: kwestiami instrumentalizacji sztuki i ekonomizacji kultury (por. Franczak 2015). Na artystów zaliczających się jednocześnie zarówno do klasy kreatywnej, jak i do grona prekariuszy, zaczęto patrzeć przez pryzmat obu perspektyw jako na grupę, którą charakteryzuje nietypowy i niepewny charakter pracy, który wymaga środowiska instytucjonalnego i prawnego wspierającego twórczość artystyczną7. W obszarze dyskursu artyści stali się grupą nie bezinteresowną, ale taką, o której interesy należy zadbać. Bezinteresowność przestała być imperatywem wewnętrznym artystów, nadal jednak, pomimo dyskursowych założeń przeciwnych, jest ich narzucaną zewnętrznie (poprzez praktyki instytucji wystawienniczych) charakterystyką. W 2002 roku Supergrupa Azorro ${ }^{8}$ stworzyła wideo Propozycja, przedstawiające artystów odsłuchujących nagranie automatycznej sekretarki, w którym grupie zostaje złożona propozycja udziału w prestiżowej wystawie. Twórcy zostają poinformowani jednak, że nie będzie on gratyfikowany finansowo. W charakterystycznym dla siebie stylu, członkowie grupy kwitują nagranie śmiechem.

${ }^{5}$ Pojęcie to wprowadził Richard Florida w książce Narodziny klasy kreatywnej.

6 Termin zaproponowany przez socjologa Guya Standinga w książce Prekariat. Nowa niebezpieczna klasa, dla opisania grupy społecznej ludzi pozbawionych podstawowych zabezpieczeń socjalnych czy chociażby nadziei na stałość zatrudnienia.

${ }^{7}$ Rezolucja Parlamentu Europejskiego z dnia 7 czerwca 2007 roku w sprawie statusu społecznego artystów.

${ }^{8}$ Grupa artystyczna powstała w 2001 roku, tworząca w obszarze sztuki wideo. Medium wykorzystywali głównie do dokumentacji swoich akcji artystycznych. Główny temat działania grupy stanowiła kontestacja świata sztuki. Należeli do niej: Oskar Dawicki, Igor Krenz, Wojciech Niedzielko, Łukasz Skąpski. 
Wykorzystana artystycznie przez Supergrupę Azorro sytuacja, choć coraz mniej powszechna, nadal nie należy do rzadkości. Zarządzający placówkami wystawienniczymi, jak wynika ze zrealizowanych $\mathrm{w}$ ramach badania wywiadów, z reguły sytuację niewynagradzania artystów za udział w wystawie uważają za niedopuszczalną. Jeden z badanych dyrektorów stwierdza.

Najważniejsza rzecz, instytucje kultury powinny wreszcie zrozumieć i przyznać się do tego, że podstawą ich pracy są artyści. Dzięki artystom instytucje kultury i galerie wystawiennicze istnieją, więc nie może tak być, że instytucje kultury nie płacą artystom za wystawy, za projekty $\mathrm{i}$ ich nie wspierają, więc tu jest bardzo duże nieporozumienie.

Odnośnie do powinności wynagradzania artystów wszyscy badani są zgodni, jednak we własnej praktyce nie zawsze stosują się do tej reguły. Rozmówczyni jednej z najbardziej rozpoznawalnych galerii non profit w Polsce stwierdziła na przykład, że już sama możliwość wystawienia się w ich przestrzeniach może być uznana za formę gratyfikacji, szczególnie jeśli wystawie towarzyszy katalog. Kierujący mniejszymi galeriami non profit przyznawali, że chcieliby wynagradzać artystów, ale nie mają na to środków, starają się więc zapewnić im możliwie największą promocję, m.in. poprzez publikacje. W przypadku galerii publicznych często w rozmowie o gratyfikacji artystów pojawiało się stwierdzenie: „staramy się ich wynagradzać". Zrealizowane wywiady wskazują, że na poziomie dyskursu artyści zostali odmitologizowani i przyznano im prawo do czerpania korzyści finansowych z wykonywanych zajęć, jednak w praktyce, z różnych powodów, nadal nie zawsze otrzymują za swą pracę wynagrodzenie. Sami artyści mają świadomość niesprawiedliwości swej sytuacji, której towarzyszy nierzadko frustracja potęgowana przez obserwację rzeczywistości pozaartystycznej: „To nawet mechanik samochodowy zarabia więcej, bo jak jadę do mechanika czy jak idę do dentysty, to on chce konkretne pieniądze za konkretne rzeczy, a jak ja mówię, że chcę tyle za rysunek, to wszyscy mówią: «Nie no za to? To jest przecież parę kresek»". Jak widać więc, bezinteresowność artystów wynika w większej mierze z narzuconych praktyk instytucji wystawienniczych niż z wewnętrznej potrzeby artystów. By nie być jednostronną, zaznaczę, że właściciele galerii komercyjnych w wywiadach narzekali niekiedy na nieuczciwe postawy artystów, którzy wiążąc się z galeriami, korzystając z ich wsparcia promocyjnego, swoje obrazy sprzedają również bezpośrednio zainteresowanym po znacznie niższych cenach.

Zdaniem Beckera, etykietowanie jest związane z hierarchią społeczną, zajmowaną pozycją. $Z$ punktu widzenia instytucji wystawienniczych bezinteresowny artysta nie jest dewiantem. W optyce niezainteresowanych sztuką, pragmatycznie myślących przedstawicieli społeczeństwa, ktoś, kto godzi się na nieotrzymywanie wynagrodzenia za swoją pracę, może zostać uznany za dewianta. Artyści natomiast pomimo diagnozowania sytuacji, w jakiej się znajdują, jako nienormalnej, bezpośrednio odpowiedzialnych za nią nie etykietują jako dewiantów być może dlatego, że pozostają w sytuacji zależności od instytucji wystawienniczych. 
Godzą się więc na dyktowane przez nie warunki, a nawet gotowi są sami dopłacać do wystaw:

Artyści są do tego przyzwyczajeni, że nie wszystko się dostaje, że dostaje się zazwyczaj miejsce i ewentualnie jak ktoś ma podpisane jakieś umowy, to jakieś druki czasami wychodzą, jakieś plakaty i zaproszenia zazwyczaj. No, ale wiadomo, wernisaż jakiś albo większe publikacje, to musimy już dopłacać ze swoich.

Innym wyjaśnieniem tej sytuacji może być ciągłe, pomimo zachodzących w świecie zewnętrznym zmian, trwanie przedstawicieli świata sztuki w mitologii romantycznej. Reprezentanci instytucji swoje relacje z artystami określają jako formę „zawodowej przyjaźni”. Jak deklaruje jedna z badanych:

Ja uważam, że w sytuacjach takich niewielkich galerii, jakimi są ciągle galerie polskie, to te relacje powinny być takimi relacjami bardzo dobrymi, wręcz właśnie przyjacielskimi. Często zdarzają się relacje takie naprawdę przyjacielskie również na gruncie towarzyskim, ale powinna być to taka dobra zawodowa przyjaźń, poleganie na sobie i jakby świadomość, że każda ze stron będzie lojalna i chętna do tej współpracy, a nie nastawiona na przykład wrogo.

Można odnieść wrażenie, że bezinteresowni artyści akceptują opisaną wyżej sytuację, która nie oddziałuje na ich relacje z przedstawicielami placówek wystawienniczych. Problem zaś jest przeniesiony poza środowisko artystyczne. Winą za trudne warunki bytowania artyści zazwyczaj obarczają wadliwy aparat państwowy.

Kolejnymi mitami, istotnymi z racji zaproponowanej optyki, jest wyjątkowość i indywidualność. Są to wartości niezwykle w świecie sztuki pożądane, jednak trudno osiągalne. Jak zauważa jeden z badanych:

Młody twórca, który kończy na przykład akademię artystyczną, właściwie jest naoglądany różnych rzeczy, obrazów, mam tu na myśli nie tylko obrazy w obszarze tradycyjnych technik, ale przede wszystkim jest atakowany obrazami z zewnątrz $\mathrm{w}$ formie filmów popularnych, wideo-artu, tego wszystkiego, co się dzieje w obszarze sztuk performatywnych; w każdym razie ma ogromną z jednej strony wiedzę, a $\mathrm{z}$ drugiej strony jest właściwie zaszczuty tym wszystkim, co już zostało w sztuce stworzone, więc żeby znaleźć jakiś osobisty sposób wypowiedzi, który oczywiście nie polega na wynalezieniu prochu, tylko polega na tym, że często bierze się pewne fragmenty rzeczy, które zostały już stworzone, i z tego tworzy się jakiś bardzo indywidualny sposób opowiadania o świecie, i to wymaga i hartu ducha, i ogromnej wiedzy, i ogromnej pracy.

Syzyfowość dążenia do wyjątkowości i indywidualności doskonale oddaje wideo przytaczanej już Supergrupy Azorro Wszystko już było z 2003 roku, w którym artyści spędzają czas, próbując wymyślić, co nowego można jeszcze w sztuce zaproponować. Każdy pomysł pointują stwierdzeniem, że „to już było”.

Dążenie do wyjątkowości artystycznej potęgowane jest przez wymogi kultury współczesnej. Kultura ta akceptuje różne formy indywidualności, nie postrzegając ich jako dewiację. Wynika to ze wzmożenia postaw tolerancyjnych również 
w naszym kraju. Co więcej, w kulturze współczesnej, podobnie jak w przypadku kreatywności w ogóle, obowiązuje wszechobecna wyjątkowość i niepowtarzalność, każdy powinien w niej być wyjątkowy. W kulturze indywidualizmu ${ }^{9}$ trudno w oparciu o te uzasadnienia budować kategorię artyzmu. Tym bardziej zatem indywidualność i wyjątkowość jest cechą pożądaną w środowisku artystycznym. Frustracje artystów może budzić niemożność sprostania tym wymogom, zważywszy że społeczny próg indywidualności i wyjątkowości został podniesiony bardzo wysoko, a w świecie sztuki również trudno znaleźć niepowtarzalną formę wyrazu, unikatowy i rozpoznawalny styl. W popkulturze Andy Warhol funkcjonuje nie tylko dzięki swoim pracom, ale również dzięki ekstrawaganckiemu sposobowi bycia, charakterystycznemu wyglądowi. Dziś artyście trudno zbudować swój image w oparciu o atrybuty zewnętrzne, związane z wyglądem, chyba że stanowi on integralną część pracy twórczej, jak ma to niekiedy miejsce w przypadku twórczości body art-owej. Działania z obszaru body art-u związane ze skaryfikacją czy innymi modyfikacjami ciała, w kręgach pozaartystycznych, ale i wśród niektórych artystów traktowane bywają jako dewiacyjne.

Ostatnim mitem, na którym chciałabym się skoncentrować, jest - kluczowa w rozważaniach na temat artystów - kwestia wolności artystycznej. Wartość ta stanowi jedno z najbardziej problematyzowanych zagadnień świata artystycznego. Artyści postrzegani są, podobnie jak intelektualiści, jako środowisko opiniotwórcze. Jak zauważa Anda Rottenberg: „Artysta po prostu patrzy na te drażliwe punkty. Te «pryszcze» naszej rzeczywistości” (Łopat). Spoczywa na nim niejako moralny obowiązek wypowiadania się w kwestiach istotnych społecznie. Artyści, korzystając ze swej wolności twórczej, choć w dużej mierze zmitologizowanej, etykietują dewiacyjne zachowania społeczne, polityczne czy gospodarcze. Ich wypowiedzi z reguły przyjmują radykalny charakter. Jednocześnie więc badając granice wolności artystycznej, sami wykonują kroki w kierunku zachowań dewiacyjnych.

Próby takie w najnowszej historii sztuki polskiej podejmowali m.in., formułując $\mathrm{w}$ swych happeningach antykomunistyczne przekazy, członkowie Pomarańczowej Alternatywy. W latach 90. granice wolności twórczej eksplorowała na polu obyczajowości swą piramidą martwych zwierząt Katarzyna Kozyra, a na początku XXI wieku Zuzanna Janin, dzięki wideo I've seen my death oszukując środowisko artystyczne w kwestii własnej rzekomej śmierci, czy Dorota Nieznalska Pasja, w której sięgnęła po symbole religijne, co spotkało się z falą oskarżeń o obrazę uczuć religijnych. W swej twórczości komentującej bieżącą sytuację społeczno-polityczną do prowokacji ucieka się grupa The Krasnals. Ryzykownie z wolności wypowiedzi artystycznej skorzystał Paweł Althamer, umieszczając przed Pałacem Prezydenckim w Warszawie, z okazji ósmej rocznicy katastrofy smoleńskiej, alternatywny wobec fundowanych przez organy władzy pomnik

${ }^{9}$ Szerzej na temat kultury indywidualizmu piszą R. Sennet (2009) czy M. Jacyno (2007). 
- rzeźbę w brzozie - Lecha Kaczyńskiego. Prowokacyjne, kontrowersyjne, kontestacyjne dzieła sztuki badają wolność artystycznego przekazu, unaoczniają jej prawne i obyczajowe granice. Artyści sięgający po radykalne formy wypowiedzi, ryzykują przypisanie im etykiety dewianta. Artyście, który otrzymuje etykietę kontrowersyjnego, trudno zmienić sposób wyrazu. W przypadku kontrowersyjnych wypowiedzi artystycznych mamy do czynienia ze swego rodzaju żonglerką etykietami dewianta. Artyści poprzez swoje prace etykietują grupy, których dotyczy ich wypowiedź artystyczna. Grupy te zazwyczaj, nie pozostając dłużne, postępowanie artystów etykietują jako dewiacyjne. Artyści natomiast z reguły nie zgadzają się z regułami, wedle których są oceniani, a co za tym idzie, ich krytycy uznawani są przez nich za Beckerowskich outsiderów (Becker 2009: 5).

Wolność artystyczna ograniczana jest nie tylko poprzez zinstytucjonalizowane cenzurowanie treści, przepisy prawne czy normy obyczajowe. Wolność ta zagrożona jest również przez układy sił w polu artystycznym. Jak stwierdza jeden z badanych, największe współczesne wyzwanie artystów to opieranie się dominacji kuratorów:

W przypadku galerii sztuki współczesnej to jednak kuratorzy nadają rytm tym wystawom. Decydują o tym, o czym artyści będą mówić, a nie wiem, czy to nie jest odwrócony porządek, czy nie jest lepiej, jak artyści sami sobie wybierają tematy do pracy, gdzieś te tematy chyba wiszą w powietrzu, natomiast nie zawsze się trzeba chyba dopasowywać do koncepcji, a coraz częściej tak jest.

Innym czynnikiem ograniczającym wolność artystyczną jest konieczność wpisywania swej twórczości w programy dotacyjne i stypendialne. Jak zauważa inny z artystów biorących udział w badaniu: „Jeśli coś od kogoś dostajesz, to jesteś też do czegoś zobowiązany”. Kolejna rozmówczyni ocenia system dotacyjny mniej jednoznacznie: „Na pewno jest to taka pułapka, że ktoś może się nauczyć funkcjonować w tym obiegu, ale ja bym tego nie oceniała jednoznacznie negatywnie, dlatego że uważam, iż artyści mają różną konstrukcję psychiczną i kogoś to może zniszczyć, a ktoś może, no po prostu są bardzo różnymi ludźmi”. Większość artystów dość bezkrytycznie podchodzi do programów dotacyjnych, widząc w nich szansę nie tyle na rozwój twórczości, co na utrzymanie. Ich zastrzeżenia budzi natomiast brak stabilności związany z uzależnieniem swej przyszłości od źródeł dotacyjnych: „Raz się dostanie, raz nie, trudno to przewidywać. Jeżeli ktoś dostaje przez rok coś, albo raz na jakiś czas, to jest super, ale nie jest to strategia na całe życie, nie da się, bo niektóre rzeczy się kończą".

Wolność, która jest kluczową wartością, nie tylko artystyczną, ale i społeczną, w każdej epoce spotyka się z różnego rodzaju ograniczeniami. W dzisiejszej rzeczywistości społecznej, zrewidowanej w kwestii władzy i wolności przez rozważania Michela Foucaulta ${ }^{10}$, w której jednocześnie walcząc o wolność

${ }^{10}$ Foucault, koncentrując się na problematyce władzy, ukazuje jej przekształcenia, jej relację do dyskursu, jednocześnie wskazując na możliwe sposoby walki o wolność. 
rozumianą jako ideę, na poziomie praktycznych rozwiązań wyzbywamy się jej w imię bezpieczeństwa, polepszenia warunków życia i innych korzyści, nie dziwi, że artyści również zrzekają się swej wolności artystycznej, podporządkowując się woli kuratorów, wymogom programów grantowych czy innym ograniczeniom pozwalającym im funkcjonować w świecie sztuki. Cena sukcesu, jaką jest m.in. ograniczenie wolności artystycznej, może jednak budzić frustrację.

Perspektywa Beckera pozwala zobrazować płynność i zmienność w czasie zachowań postrzeganych jako dewiacyjne, a także względność etykietowania (to, co w świecie pozaartystycznym postrzegane jest jako dewiacja, wśród artystów nie otrzymuje takiej etykiety i odwrotnie). Dotyczy to zarówno bezinteresowności, która obecnie nie jest wartością oczekiwaną nawet w świecie artystycznym (co, jak wykazałam, nie oznacza, że artyści z konieczności nie zachowują się bezinteresownie), jak i wolności, indywidualności oraz wyjątkowości. O ile jeszcze kilkanaście lat temu etykieta „artysty-wariata” mogłaby wynikać z ekstrawagancji artystycznej (mit indywidualności), o tyle w dzisiejszym społeczeństwie, coraz mniej wyczulonym na odmienności, etykieta ta w większym stopniu może konstruować się w oparciu o bezinteresowność artysty, postrzeganą jako nieżyciowość, a nawet naiwność. W świecie artystycznym natomiast artysta może zyskać etykietę dewianta z racji rezygnacji z wolności twórczej na rzecz stabilności ekonomicznej czy sławy.

W dalszej części tekstu chciałabym przyjrzeć się zachowaniom dewiacyjnym artystów wynikającym z nakładania się na siebie świata sztuki i rzeczywistości pozaartystycznej w kontekście ekonomicznym. Do tego celu posłużę się koncepcją Roberta Mertona. Zbudowana została ona na podstawie obserwacji społeczeństwa amerykańskiego lat trzydziestych, posiadającego jasno sprecyzowane cele, odnoszące się do idei american dream, w którym sukces mierzony jest uzależnioną od zasobności portfela pozycją społeczną. Merton w ujęciu funkcjonalno-systemowym nie koncentrował się na przyczynach powstawania anomii, względności i płynności zachowań dewiacyjnych. Jego typy indywidualnego przystosowania stanowią schematyczną matrycę klasyfikowania zachowań. Wypowiedzi badanych na temat ich sytuacji społeczno-ekonomicznej i prób odnalezienia się w bieżących realiach pozwoliły na wyłonienie kilku sposobów zachowania, które spróbuję zestawić z Mertonowskimi typami indywidualnego przystosowania (Merton 2002). Typologia Mertona zakłada, że istnieją społecznie akceptowalne w społeczeństwie cele oraz powiązany z nimi system wartości charakteryzujących dane społeczeństwo. W sytuacji, w której realizacja celów jest utrudniona, jednostki skłonne są do zachowań dewiacyjnych.

W Polsce, jak wynika z Diagnozy społecznej 2015 roku, najczęściej wskazywaną wartością jest zdrowie, następnie udane małżeństwo, dzieci, praca i pieniądze (Czapiński 2015: 272). Jakie cele i wartości przyświecają artystom? Z ich wypowiedzi wynika, że najważniejsza jest dla nich możliwość tworzenia, wyrażania siebie. Ta jednak nie zapewnia im środków do egzystencji, przeciwnie, jest 
ograniczana przez sytuację ekonomiczną artystów. Celem artystów jest możliwość utrzymania się ze sztuki. Nie mówili oni, być może z racji szczerej lub fałszywej skromności, o odnoszeniu sukcesów, robieniu kariery. Twierdzili, że najważniejsze jest dla nich tworzenie nieokupione problemami finansowymi i obciążeniami dla rodziny. Badani przyznawali, że albo ich sytuacja spotyka się z dezaprobatą innych członków rodziny, albo nawet, jeśli spotykają się ze wsparciem, odczuwają oni dyskomfort. Niektórzy przyznawali również, że zrezygnowali z posiadania rodziny (albo opowiadali o takich decyzjach innych artystów) z powodu niestabilnej sytuacji ekonomicznej artystów. Jak widać, poza zdrowiem, cele i wartości ogółu społeczeństwa polskiego pokrywają się z systemem wartości i celami życiowymi artystów, przy czym ich osiągnięcie przez analizowaną grupę napotyka trudności, a zdaniem wielu jest wręcz niemożliwe. Artyści uważają, że talent nie stanowi gwarancji sukcesu artystycznego. Ten zaś, nawet jeśli uda się go osiągnąć, nie przekłada się na stabilizację ekonomiczną, która, jak zauważa jeden z badanych: „Generalnie jest beznadziejna, jeżeli nie ma się jakiegoś zahaczenia typu znajomości, polecenia tudzież łut szczęścia, to jest słabo". Inny rozmówca natomiast sygnalizuje ukrywanie problemu: „Wydaje mi się, że ta sytuacja artysty jest trudna, ale jak się zapyta w szerszym gronie, to nikt się nie przyzna, zaraz go ocenią, że jest sfrustrowany, to sfrustrowanemu nie zrobi się wystawy".

Jak zatem do zaistniałej sytuacji przystosowują się artyści? Wielu artystów łączy talent i predyspozycje przedsiębiorcze, albo uczestniczy w programach pokrywających się z ich credo artystycznym, wpisując się wówczas w postawy konformistyczne. Większość badanych stanowili artyści pracujący w uczelniach artystycznych. Przyznawali oni, że dla artysty jest to najlepsza droga kariery w polskich realiach. To konformistyczne również podejście pozwala bowiem na pewną stabilizację finansową i daje możliwość rozwoju. Ci, którzy mają trudności lub nie są w stanie utrzymać się ze swej twórczości, sięgają po zachowania nonkonformistyczne.

Pierwszy model postępowania nonkonformistycznego można określić jako rynkowy. Artyści w tej perspektywie nie utyskują na swoje trudne położenie. Cechuje ich pragmatyzm, a nawet cynizm. Korzystając z optyki Mertonowskiej, ich zachowania można uznać za innowacyjne, czyli takie, przy których akceptuje się ogólnie przyjęte cele, ale odrzuca przyjęte sposoby ich osiągania. Zaistnienie w świecie sztuki zapewnia artystom wówczas nie talent i praca twórcza, czasem nawet nie edukacja artystyczna, ale konsekwentne wypracowywanie swojej pozycji w środowisku. Artysta w tej optyce konsekwentnie buduje swoją karierę poprzez stałe odwiedzanie instytucji wystawienniczych, galerii oraz domów aukcyjnych, poprzez nawiązywanie kontaktów. Sytuacja społeczno-ekonomiczna artysty, zdaniem badanych, w dużej mierze zależy od pracowitości, znajomości środowiska artystycznego, realiów rynku sztuki oraz zaradności, co obrazuje poniższy cytat: „Poznałem dużo osób przez aukcje, które dają radę [te osoby] się utrzymać tylko ze sztuki [...], ale wiele osób nie zdaje sobie sprawy, że można 
gdzieś iść, pokazać swoje prace w domu aukcyjnym i ktoś ich przyjmie”. W podobnym tonie utrzymana jest kolejna wypowiedź: „Jest taka wąska grupa, która wysiaduje gdzieś albo w instytucjach kultury, zbliża się do kuratorów, siada na kanapie i coś tam wysiedzi, jakiś wyjazd czy stypendium, jakieś wsparcie, to jest ciągle sytuacja proszącego". Innym, równie innowacyjnym postępowaniem jest podporządkowanie swej twórczości konkursom i programom finansującym działania artystów. Artyści wówczas, zamiast traktować swoją twórczość jako indywidualną formę wyrazu artystycznego, tworzą prace podporządkowane tematyce i optyce programu czy konkursu. „Tworzy jakieś projekty skonstruowane na rzecz pewnych doraźnych celów wskazanych przez grantodawcę, które nie są może kulturowo trwałe", przyznaje jeden z artystów. Za jeszcze inną formę zachowań innowacyjnych można uznać działania artystyczne obliczone na wywołanie kontrowersji, a nawet skandalu.

Inny sposób odnalezienia się w bieżących realiach przypomina Mertonowskie wycofanie, polegające na rezygnacji z aspiracji tworzenia możliwie najlepszej sztuki na rzecz świadomej przeciętności. Jeden z badanych opowiada:

Można się uplasować w bardziej przyziemnej dla ludzi sztuce i ludzie żyją z tego też. Robią obrazy, które u nas na akademii powiedzieliby, że jest to słabe albo niezbyt interesujące malarstwo czy grafiki, ale jest na to popyt, więc można się z tego utrzymywać. Znam też jednego [badany podaje imię], który jest super, jeśli chodzi o technologię malarstwa i warsztatowo wykształcony, i on mówi, że z tego żyje, bo zawsze ktoś się znajdzie na coś takiego, ale na akademii by ci powiedzieli, że to nie jest już sztuka, tylko bardziej warsztat i rzemiosło, ale jak nie możesz być sławny, czy nigdy nie chciałeś być, to możesz żyć tak i też sobie poradzisz

Wycofanie może sprowadzać się również do zupełnej rezygnacji z działalności artystycznej. Zdaniem badanych jest to bardzo dotkliwa sytuacja, szczególnie dla młodych ludzi, którzy muszą zrezygnować ze swoich ambicji na rzecz zapewnienia stabilizacji finansowej: „Największy dramat współczesnego absolwenta to, że albo postawi wszystko na jedną kartę, zdając sobie sprawę z tego, że może przegrać wszystko, albo tak naprawdę zrezygnować ze sztuki i oddać się mass mediom i pracy, która przyniesie mu zarobek”. Najczęściej artyści sięgają po zachowania oportunistyczne: znajdują bezpieczne źródło utrzymania, nie rezygnując zupełnie z pracy twórczej, którą traktują jako zajęcie „po godzinach”, albo takie, do którego kiedyś się powróci. „Jest grono osób, które zaczepiają się w szkolnictwie, co na ogół daje margines czasu, żeby jeszcze coś robić. A reszta się przekwalifikowuje w taki sposób, że już nie mają tego marginesu czasu i stopniowo zaprzestają mieć aspiracje artystyczne", przyznaje badany.

Gros artystów nie ma pomysłu na odnalezienie się w rzeczywistości. Ich postawa bliska jest Mertonowskiemu rytualizmowi, czyli konsekwentnemu trzymaniu się tradycyjnych norm i zasad, bez analizowania celów swej działalności. Artyści ci wpisują się w mitologie zebrane przez Wejbert-Wąsiewicz. Nie potrafią oni, jak przyznaje jeden z badanych, funkcjonować na rynku sztuki, ale się do tego 
nie przyznają, nie chcą zaakceptować rzeczywistości: „Jeżeli ma się zaplecze, że jest się na utrzymaniu rodziny, to jest świetnie, ale jak samemu ma się na utrzymaniu rodzinę, to wielu artystów funkcjonuje na totalnym minimum. Mamy wielu bardzo dobrych artystów, którzy są w takiej sytuacji i to jest trochę ukryte, bo nie opowiadają o tym”. Inny twórca przyznaje: „Wystawiałem się w tych wszystkich superinstytucjach, tylko u mnie się to nie przekładało na, wprost mówiąc, kasę. Może, jak wspomniałem, jest to zbyt, nie potrafiłem wykorzystać momentu czy wykorzystać sytuacji. Też trzeba umieć, nie?"

Postawy rytualne charakteryzują artystów w różnym wieku. Badani zauważają, że akademia nie daje im żadnych wskazówek odnośnie do postępowania w świecie sztuki. Młodzi ludzie po studiach często przekonani są, że sam talent wystarczy, by odnieść sukces. Zamykają się w świecie swojej twórczości, której nie potrafią jednak wprowadzić do obiegu artystycznego, a w Polsce rynek sztuki nie jest na tyle sprofesjonalizowany, by stworzyć i utrzymać system menadżerski obsługujący artystów.

Wśród artystów pojawiają się również postawy buntownicze, które znajdują wyraz zarówno w działaniach w rzeczywistości społecznej, jak i artystycznej. W maju 2012 roku odbył się w Polsce protest artystów plastyków zainicjowany przez Obywatelskie Forum Sztuki Współczesnej pod hasłem „Strajk! - Dzień bez sztuki”. Wielu twórców poprzez swą twórczość kontestuje sytuację, w jakiej znajdują się artyści, czego przykładem mogą być działania, które podejmowała Supergrupa Azorro. Zbigniew Libera również aktywnie działa na rzecz zmiany sytuacji ekonomicznej artystów. Jednym z przykładów takiego działania jest fotografia, na której trzyma kartkę z napisem „Jestem artystą, ale to nie znaczy, że pracuję za darmo".

Jak zatem świat sztuki może wyjść z sytuacji anomii? Co może zmienić sytuację artystów? Jak deklarują sami zainteresowani, po pierwsze konieczne są zmiany regulacji prawnych:

To, co w końcu się zaczęło dziać, co robi Obywatelskie Forum Sztuki Współczesnej, to, co robi teraz związek zawodowy Inicjatywa Pracownicza. Oni są świeżym związkiem, ale próbują to, co Obywatelskie Forum Sztuki Współczesnej. Próbują przekonać ministerstwo, żeby wprowadzić system jakiegokolwiek zabezpieczenia socjalnego dla artystów, który byłby ciągły, który by uwzględniał specyfikę naszego zawodu, gdzie zarobki są sinusoidalne totalnie i ma się zlecenie, to się ma, a jak się nie ma, to się nie ma.

Badani wskazują również, że społeczeństwo polskie musi się wzbogacić, by zainteresowało się sztuką współczesną. Głównym problemem Polaków, zdaniem rozmówców, jest brak stabilizacji finansowej, w związku z czym nie mają oni ochoty ani środków, by realizować potrzeby życiowe wyższego rzędu:

Myślę, że generalnie, gdyby płace były większe i ludzie nie musieliby myśleć o tym, co włożyć do garnka jutro i żyłoby się im lepiej, to w świadomości społecznej sztuka też zaczęłaby 
istnieć na trochę innym poziomie, bo dla większości ludzi to jest rzecz zupełnie niepotrzebna i poza myślami. Obrazy czy grafiki nie są artykułem pierwszej potrzeby.

Dobrym pomysłem, zdaniem badanych, jest nawiązanie partnerstwa z prywatnymi podmiotami gospodarczymi. $\mathrm{Z}$ powodu braku zainteresowania sztuką współczesną społeczeństwa, w tym środowisk biznesowych, możliwość takiej współpracy jest mało prawdopodobna:

To jest, wydaje mi się bardziej skomplikowane, bo owszem można dostać grant, to są pieniądze z miasta, z Unii i tak dalej. Myślę, że dobrym partnerem byłby partner prywatny, firmy, instytucje, ale ci ludzie muszą mieć świadomość - nie mają takiej świadomości, bo na drodze swojej kariery zawodowej czy funkcjonowania w tym świecie nie nabyli tego, ale powód jakby jest dość głęboki, tego się nie uczy. Ci ludzie nie są zaznajomieni akurat z tą dziedziną życia.

Pojawiła się także wypowiedź, która sugeruje, że nie ma konieczności wspierania twórców: „Ja nie uważam, żeby coś trzeba było robić. Roszczeniowa postawa artysty to jest też dosyć częsta rzecz. Artysta zapatrzony w swoją romantyczną wizję. Bo jeszcze ta wizja romantycznego artysty ciągle funkcjonuje w Polsce". Propozycje podawane przez artystów, choć w niektórych przypadkach trudne do urzeczywistnienia, wskazują kierunki wyjścia z sytuacji anomii. Pierwszym krokiem powinno być unormowanie legislacyjne sytuacji artystów, zapewnienie im zabezpieczeń socjalnych, a także ubezpieczeń zdrowotnych i chorobowych oraz dostosowanie zasad podatkowych do charakteru pracy twórców. Drugim obszarem wymagającym przekształceń jest sprofesjonalizowanie współpracy pomiędzy placówkami wystawienniczymi a artystami, stosowanie stawek rynkowych dla wynagradzania ich pracy, ale i stworzenie systemu prawnego umożliwiającego egzekwowanie zobowiązań przez artystów względem galerii komercyjnych. Trzeci aspekt to wzmacnianie świadomości społecznej w zakresie sztuki. Oczywiście, poziom życia społeczeństwa ma wpływ na miejsce, jakie zajmuje w nim kultura i sztuka. Wszyscy życzylibyśmy sobie wzrostu zarobków, trudno jednak traktować ten postulat jako wdrożeniowy. Warto jednak zwrócić uwagę, co zresztą w coraz większym stopniu jest uwzględniane przez polityki kulturalne, na konieczność budowania świadomości społecznej w zakresie sztuki współczesnej poprzez szeroko zakrojoną działalność edukacyjną. Należy podkreślić, że placówki wystawiające sztukę współczesną od kilku lat prowadzą intensywne działania edukacyjne towarzyszące działalności wystawienniczej. Wreszcie, odnosząc się do wypowiedzi badanych, konieczne jest w obliczu zmian związanych z ekonomizacją kultury, dążenie do zniesienia alienacji świata artystów od świata gospodarki i biznesu. Normatywny model artysty współczesnego wymusza bowiem na nim myślenie przedsiębiorcze, a na sztuce podejście rynkowe. Ważne jest, by zmiany te następowały równomiernie. W przeciwnym razie mogą prowadzić do patologii. 
Urynkowienie sztuki ma, zdaniem badanych, sens jedynie przy wzroście zainteresowania społecznego tą dziedziną kultury, do czego może się przyczynić edukacja artystyczna. Alternatywnym sposobem budzenia popytu, negatywnie jednak oddziałującym na sztukę, jest jej homogenizacja upraszczająca (por. Kłoskowska 1980). Urynkowienie oznacza dla badanych, w kontekście odbiorców - upowszechnienie, w kontekście dzieł - uprzystępnienie, rozumiane jako uproszczenie. W obecnej sytuacji braku popytu na sztukę, konkurencyjność przyjmuje niekontrolowaną postać: „Przecież teraz [...] każdy się produkuje w różny sposób albo żeby dotrzeć do jakiegoś człowieka, który decyduje, żeby dać stypendium, czy coś na wystawę i tu się ludzie zabijają teraz między sobą, tu jest teraz patologia [...]. Wtedy, kiedy jest więcej do wyboru, to ludzie może się trochę mniej żrą, że się tak wyrażę". Wzmożone zainteresowanie sztuką współczesną byłoby również korzystne dla studentów, którzy zyskaliby większą motywację i chęci do działania, co widać w kolejnej wypowiedzi: „Wydaje mi się, że to bardzo by wpłynęło na sztukę polską $\mathrm{w}$ takim sensie, że młodzi artyści, którzy by byli kształceni w takich warunkach, po prostu wiedzieliby, że to, co robią, jest wartościowe, taki rozwój jest zupełnie czymś innym". Do tezy o potrzebie wzmożenia popytu na sztukę przychyla się również kolejny rozmówca:

Spożycie ogórków przekłada się na to, jak funkcjonuje rynek produkcji ogórków. Jeżeli odbiór byłby większy, bardziej zrozumiały, przede wszystkim może te czynniki decyzyjne zaczęłyby to dostrzegać w sposób pełniejszy. Czyli to, co mówiliśmy wcześniej: granty, finansowanie, rozwiązania prawne. To by wymuszało inne rzeczy, większy odbiór.

Sztuka jest dziedziną kultury, która wymaga instytucjonalnego wsparcia. Paradoksalnie jednak, tylko dobrze rozwinięty, stabilny rynek sztuki jest w stanie zagwarantować artystom odpowiedni poziom życia i wolność twórczą. Może on zafunkcjonować jedynie wtedy, jeśli jednocześnie realizowane będą zmiany legislacyjne, nastąpi rozwój edukacji w zakresie sztuki współczesnej, rozwój gospodarczy i last but not least zmiany w podejściu samych artystów.

W tekście postawiłam hipotezę, że świat artystyczny znajduje się w stanie anomii z powodu ekonomicznej deprecjacji artystów, pogłębiającej się w obliczu zmian wynikających z bogacenia się społeczeństwa, nieumiejętności ich znalezienia się w sytuacji wolnorynkowej, a także z powodu zmian kulturowych, w wyniku których dewaluują się wartości do tej pory istotne w świecie sztuki. O ile w obszarze kultury świat sztuki powinien poradzić sobie sam, o tyle w obszarze ekonomii rozwiązanie musi przyjść z zewnątrz. Likwidacja sytuacji anomicznej nie jest jednoznaczna ze zniwelowaniem zachowań dewiacyjnych, szczególnie jeśli przyjmiemy optykę Beckerowską, w której dewiacje nie są powiązane z sytuacjami anomii, a wynikają z postrzegania jednostki przez grupę. Dobrze jednak, żeby dewiacyjność artystów wynikała z ich artystycznych poszukiwań, a nie prób rozwiązywania własnych podstawowych problemów egzystencjalnych. 


\section{Bibliografia}

Becker S. H. (1982), Art Worlds, University of California Press.

Becker S. H. (2009), Outsiderzy. Studia z socjologii dewiacji, thum. O. Siara, PWN, Warszawa.

Czapiński J. (2015), Indywidualna jakość i styl życia, [w:] J. Czapiński, T. Panek (red.), Diagnoza społeczna, Rada Monitoringu Społecznego, Warszawa, s. 200-321.

Florida R. (2011), Narodziny klasy kreatywnej, tłum. T. Krzyżanowski, M. Penkala, Narodowe Centrum Kultury, Warszawa.

Foucault M. (1993), Nadzorować i karać. Narodziny więzienia, tłum. T. Komendant, Aletheia, Warszawa.

Franczak K. (2015), Kultura jako źródło zysku? Etos kreatywności i wspótczesny dyskurs modernizacyjny, „Przegląd Socjologiczny”, nr 2, s. 89-112.

Jacyno M. (2007), Kultura indywidualizmu, PWN, Warszawa.

Kłoskowska A. (1980), Kultura masowa. Krytyka i obrona, PWN, Warszawa.

Łopat J., Sztuka nie zmieni świata - rozmowa z Anda Rottenberg, http://liberte.pl/sztuka-nie-zmieni-swiata-rozmowa-z-anda-rottenberg/ [dostęp 16.04.2018].

Merton R. (2002), Teoria socjologiczna i struktura społeczna, tłum. E. Morawska, J. WertensteinŻuławski, PWN, Warszawa.

Sennet R. (2009), Upadek człowieka publicznego, tłum. H. Jankowska, Muza, Warszawa.

Standing G. (2014), Prekariat. Nowa niebezpieczna klasa, tłum. K. Czarnecki, P. Kaczmarski, M. Karolak, PWN, Warszawa.

Thornton S. (2008), Seven Days in the Art World, W. W. Norton \& Company, New York.

Wejbert-Wąsiewicz E. (2009), Rola artysty w społeczeństwie, „Dwumiesięcznik społeczno-polityczny. Realia i co dalej...”, nr 4 (13), s. 109-120.

\section{Źródla internetowe}

http://nck.pl/badania/raporty/kondycja-sztuk-wizualnych-percepcja-i-spoleczny-obieg-sztuki-wspolczesnej-w-polsce [dostęp 25.04.2018].

\section{Izabela Franckiewicz-Olczak}

\section{INTERPRETATION OF ARTISTS' ECONOMICAL SITUATION IN POLAND IN THE LIGHT OF ANOMIE AND DEVIANCE THEORY}

Summary. The diffuse of artistic world and economy may lead to anomie and deviance. The article starting with typology of myths connected with artists, focuses on changes in artistic existence. The text basing on interpretative attitude of Howarda S. Beckera, analyse the changeability and relativity of artistic world deviance and making use of Merton's 5 types of deviance shows the way of artists' behaviour.

Key words: anomie, deviance, artists, selflessness, artistic freedom, artistic career. 